\title{
Hárompontos hajlító-nyíró vizsgálatnak alávetett próbatestek Euler-Bernoulli- és szilárdtest modelljeinek összevetése
}

\section{Comparison of the Euler-Bernoulli- and Solid Models of Three-Point Bending Test Specimens}

\author{
VADAI Zs. ${ }^{1}$ \\ ${ }^{1}$ University of Debrecen, Faculty of Engineering, Department of Civil Engineering, vadai@eng.unideb.hu
}

\begin{abstract}
Absztrakt. Egyszerüsége és jó pontossága miatt kézi számításokhoz a mérnöki gyakorlatban az Euler-Bernoulli gerenda modell terjedt el. Jelen tanulmányban egy vasalás nélküli és egy FRP (Fibre Reinforced Polymer, azaz üvegszálerôsítésú müanyag) betétekkel erôsített repedésmentes beton gerenda Euler-Bernoulli, valamint térbeli szilárdtest modellje alapján számított állapotjellemzőinek összehasonlító elemzését végeztem. Az Euler-Bernoulli modell esetében bemutattam az egyszerüsító feltevéseket és a vizsgált állapotjellemzők meghatározásának módját. A szilárdtest modellek megalkotása során vizsgáltam hogyan befolyásolják a különböző képpen felvett támaszmodellek a számított állapotjellemzők értékeit. Végül a valóságnak leginkább megfelelő peremfeltételekkel ellátott szilárdtest modellek alapján meghatározott állapotjellemzőket összehasonlítottam az Euler-Bernoulli modellek szerint számított értékeikkel.
\end{abstract}

\begin{abstract}
Due to its simplicity and good accuracy for manual calculations, the Euler-Bernoulli beam model has become widespread in engineering practice. In the present study, I performed a comparative analysis of the state variables of a crack-free concrete beam and a crack-free FRP (Fiber Reinforced Polymer) reinforced concrete beam calculated based on the Euler-Bernoulli and three-dimensional solid model. In the case of the Euler-Bernoulli model, I presented the simplifying assumptions and the way to determine the state characteristics examined. During the creation of the three-dimensional solid models, I investigated how the support models recorded in different ways influence the values of the calculated state variables. Finally, I compared the state variables determined based on the most realistic solid models with their values calculated according to the Euler-Bernoulli models.
\end{abstract}

Kulcsszavak: Végeselem módszer, beton gerenda, FRP betét

Keywords: Finite element method, concrete beam, FRP reinforcement 


\section{Bevezetés}

A vasbetonszerkezetekben kialakuló fémkorrózió anyag és szilárdságvesztéssel járó folyamat, melyet mindenképpen meg kell előzni, illetve el kell kerülni [1]. A korróziós problémáktól való megszabadulás egy lehetséges módja a betonszerkezetek szálerősítésű műanyag (FRP) betétekkel történő megerősítése. A vasbetonszerkezetekhez, hasonlón az FRP betétekkel megerősített szerkezetekre is dolgoztak ki méretezési és tervezési eljárásokat [2,3]. Ezen eljárások gerendák esetében az EulerBernoulli modell használatán alapulnak. A szilárdtest modellen a valóságnak jobban megfelelő terhek és megtámasztások definiálására van lehetőség, ezért cikkemben az alábbiakban bemutatott, hárompontos hajlító-nyíró vizsgálatnak alávetett gerendák összehasonlító vizsgálatát végzem repedésmentes állapotban, az Euler-Bernoulli és a végeselemes szilárdtest modelljük alapján.

A hárompontos hajlító-nyíró vizsgálat során, alsó lapján vonalmenti csuklós támaszokkal rögzített, téglatest alakú kéttámaszú gerendát, felső lapjának keresztirányú szimmetria tengelyén terhelünk vonalmentén megoszló erővel (1. ábra). A terhelő erő nagyságát 0-ról növelve, mérőóráról leolvassuk az alsó lap szimmetria pontjának függőleges irányú elmozdulását, miközben regisztráljuk a megjelenő repedéseket és repedéstágasság mérő kártyával meghatározzuk a repedések megnyílását a betétek szilárdsági tengelyének magasságában (1.ábra). Jelen cikk a homogén keresztmetszetű (a továbbiakban G1 jelű) és az FRP betétekkel erősített (a továbbiakban G2 jelű) gerendák vizsgálatával foglalkozik repedésmentes állapotban, az Euler-Bernoulli- és a térbeli szilárdtest modellek alapján. A nevezett modellek esetében az alábbi állapotjellemzők lettek meghatározva, majd összevetve:

- az alsó szélső szálban ébredő húzófeszültségek tengelyirányú eloszlása,

- az FRP betétben ébredő feszültségek tengelyirányú eloszlása (H1 esetén),

- az alsó szélső szál lehajlása.

A fenti állapotjellemzők az $F=4 k N$ nagyságú teher 1 . ábra szerinti elrendezésében lettek meghatározva. Továbbá ki lett számítva az $F$ erő azon értéke, mely hatására az alsó szélső szálban kialakul a beton hajlító-húzó szilárdságának várható értéke $\left(f_{c t m, f l}\right)$. A továbbiakban erre az erőre, mint repesztőerőre hivatkozom.
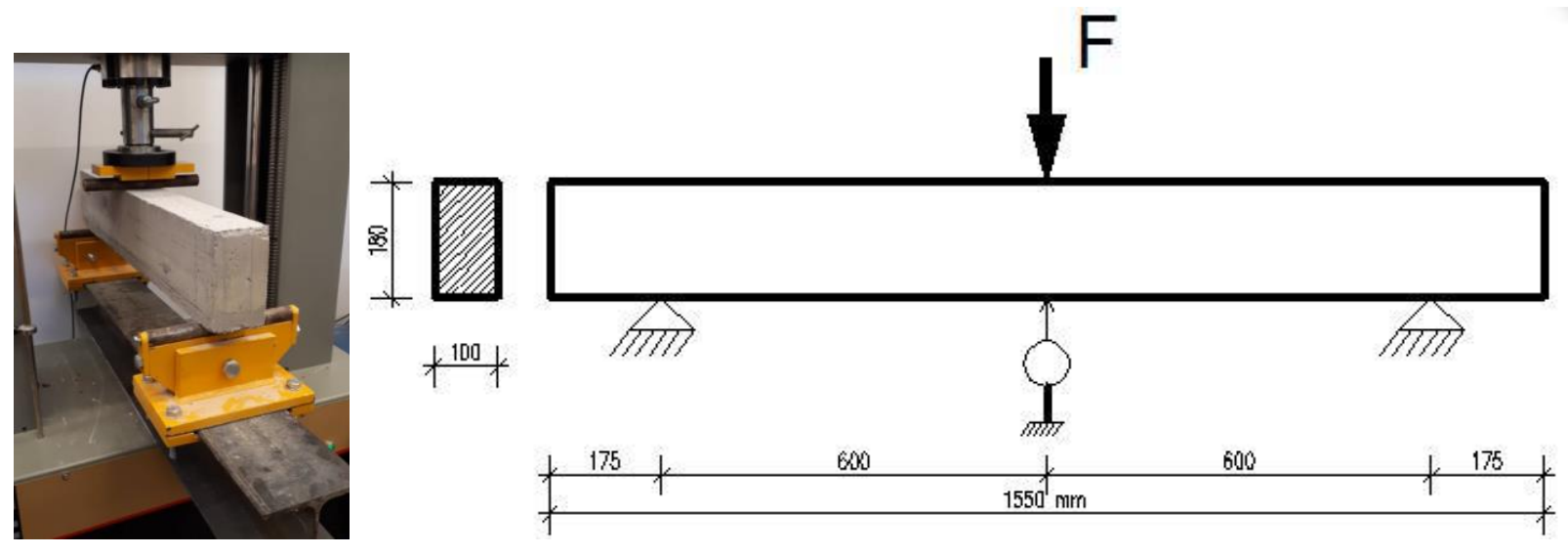

1. ábra: Hárompontos hajlitó-nyíró vizsgálat az Építőmérnöki Tanszék Anyag-és Szerkezetvizsgáló Laboratóriumában és a vizsgálat geometriai elrendezése 


\section{A gerendák}

\subsection{Geometriai méretek}

A gerendák 100 mm ×180 mm-es téglalap keresztmetszettel és 1550 mm-es hosszúsággal készültek (2. ábra). A G1 gerenda keresztmetszete megerősítés nélküli (homogén, H0). A G2 próbatest esetében a keresztmetszet alsó sarkaiban $2 \mathrm{db} 8 \mathrm{~mm}$ átmérőjü FRP hossz betét, a felső sarkokon $2 \mathrm{db} 6 \mathrm{~mm}$-es szerelő acélbetét, valamint a hossztengely irányában $150 \mathrm{~mm}$-enként $6 \mathrm{~mm}$ átmérőjű acél kengyelek lettek elhelyezve (H1 jelű vasalás).

\subsection{Anyagjellemzők}

\section{A beton}

A számításokhoz és a modellezéshez szükséges anyagjellemzők az érvényben lévő [4] szabvány alapján lettek meghatározva. A rugalmassági (szelő) modulus várható értéke $E_{c m}=27314,48 \mathrm{MPa}$, a hajlítóhúzó szilárdság várható értéke $f_{c t m, f l}=3,06 \mathrm{MPa}$.

A szálerôsítésü müanyag betétek (FRP)

A modellezés során a betonszerkezetek esetében legelterjedtebb üvegszálerősítésű műanyag (Glass Fibre Reinforced Polimer, továbbiakban GFRP) betétet használtam. A GFRP betétek rugalmassági modulusa az $[3,5,6]$ szakirodalmakban fellelhető adatok alapján $E_{f}=50 \mathrm{GPa}$ értékkel lett figyelembe véve az Euler-Bernoulli- és a végeslem modellben egyaránt.

\section{Az acélbetétek és kengyelek}

Az [4] szabványnak megfelelően az alkalmazott 150 mm-es kengyelkiosztás miatt, a felső sarkokban elhelyezett acélbetéteket nem lehet figyelembe venni nyomott acélbetétekként, valamint a kengyelezéssel sem lehet, mint méretezett nyírási vasalással számolni. Tehát az acélbetétek az EulerBernoulli modellekben nem lettek figyelembe véve. A numerikus modellek esetében az acélbetétek és a kengyelek is szilárd testként lettek beépítve, rugalmassági modulusnak a szabványos $E_{S}=200 \mathrm{GPa}$ értéket adtam. 


\section{G1 jelü gerenda, 100x180x1550, homogén km. (H0 vasalás)}

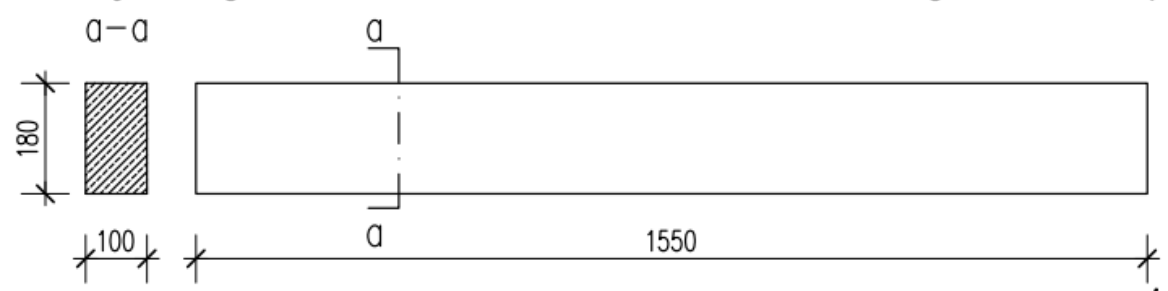

G2 jelü gerenda, 100x180x1550, 2frp $\emptyset 8,10 \varnothing 6 / 15$ (H1 vasalás)

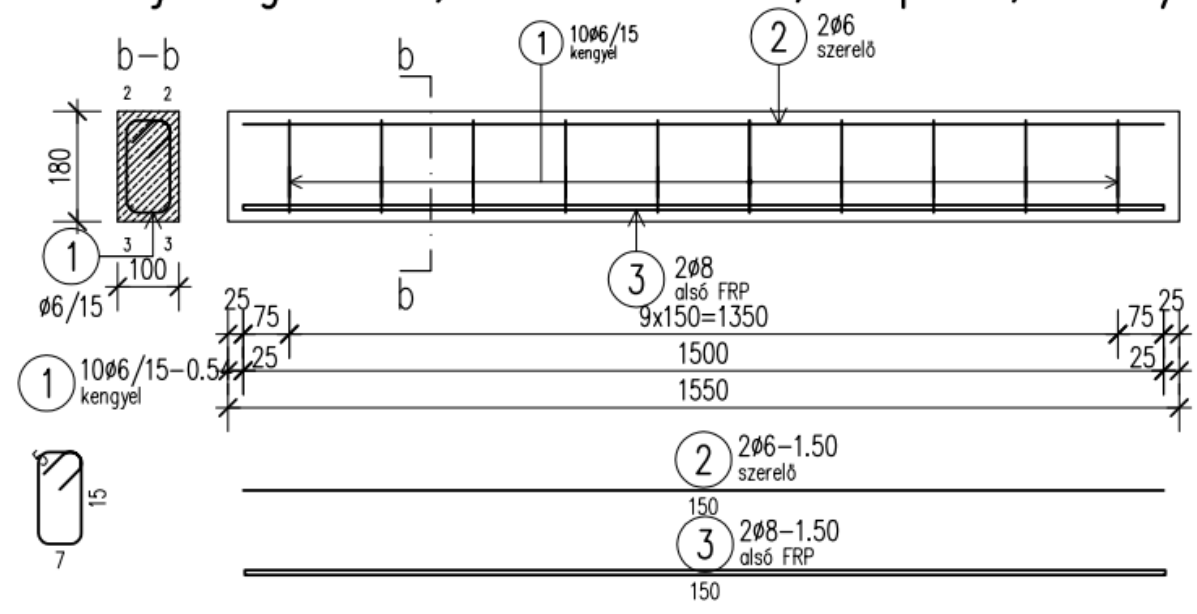

2. ábra: A próbatestek „vasalása”

\section{Az Euler-Bernoulli gerendamodell bemutatása}

\subsection{A rúdszerkezet}

Ha egy síkidom súlypontját valamilyen görbe mentén végig vezetjük, a síkidom kerülete egy rúd felületet súrol. Amikor ezen görbe egyenes és a síkidom önmagával egybevágó marad, egyenes tengelyű prizmatikus rúdról beszélünk. A síkidom a keresztmetszeti poligon, míg a görbe a rúd hossztengelye. (A görbe típusától függően megkülönböztetünk síkbeli vagy térbeli görbe, ill. egyenes tengelyű rudakat.) A rúd származtatásából következik, hogy geometriája a keresztmetszeti poligonok és azok súlypontját tartalmazó görbe ismeretében egyszerűen leírható.

\subsection{A sík és merev keresztmetszetek elve (Bernoulli-Navier-féle hipotézis)}

A rúd terheletlen állapotában a tengelyére merőleges metszetei, a terhelés hatására bekövetkező deformációk lezajlása után önmagukkal egybevágóak, és a rúd meggörbült tengelyére merőlegesek maradnak. Ezzel hajlított-nyírt tartók esetében elhanyagoljuk a nyírási alakváltozásokat. (A pontosabb elméleti és kísérleti vizsgálatok bebizonyították ezen feltételezés helyességét [7].) A sík keresztmetszetek elvének ez a megfogalmazása a hajlított-nyírt tartók mellett a központosan húzott, ill. nyomott rudakra is érvényes. Tiszta csavarás esetén csak körszimmetrikus szelvényekre igaz a fenti megállapítás, hiszen a többi keresztmetszet esetén számolnunk kell az öblösödés jelenségével. Tiszta nyírás esetén az előbbi feltevés ebben a formában nem igaz, a keresztmetszetek síkok, és önmagukkal 
egybevágóak maradnak, de nem lesznek merőlegesek a tartó „meggörbült” tengelyére, hiszen megőrzik függőleges helyzetüket.

\subsection{A kis elmozdulások elve}

A kis elmozdulások elve az általános szilárdságtanban is alkalmazott feltevés, mely szerint a szerkezetek, méreteikhez képest nagyságrendekkel kisebb elmozdulásokat végeznek. A fenti elv következményei: hogy az egyensúlyi vizsgálatot a rudak eredeti alakján végezhetjük, valamint a geometriai egyenletek linearizálhatósága. A kis elmozdulásoknak köszönhetően a trigonometrikus függvényeket közelíthetjük a MacLaurin-soruk első elemével, így az elfordulásokból kapott eltolódásokat lineáris összefüggésekből számíthatjuk.

\subsection{Az Euler-Bernoulli gerendamodell}

A fenti elvek következménye, hogy a keresztmetszetek merev testekként modellezhetők, melyek a rúd anyagának szilárdsági tulajdonságait reprezentáló végtelenül rövid rugókkal kapcsolódnak egymáshoz. $\mathrm{Az}$ infinitezimálisan rövid rugók a végtelenül vékony merev lapok között, végtelenül sűrűn helyezkednek el [7]. A rúdszerkezet statikai vázán a keresztmetszeti poligonok súlypontjainak a halmazát, valamint a támaszokat értjük. Ezen elméleti modellek esetében a tökéletesen merev támaszokat, a metszetükben lévő keresztmetszeti síkidom súlypontjában, az átadódó reakció erőkkel zérusértékű, velük munkakompatibilis elmozdulás komponensek peremfeltételként való előírásával modellezhetjük. Ha a statikai váz pontjaihoz egy-egy keresztmetszeti síkidomot rendelünk, a rúdszerkezet szilárdságtani modelljét kapjuk.

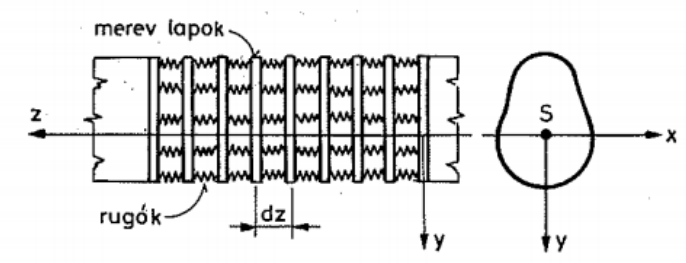

3. ábra: Euler-Bernoulli gerendamodell [7]

\subsection{Az állapotjellemzők meghatározása}

Az összehasonlítás alapját képező állapotjellemzők Euler-Bernoulli modellen történő meghatározásához először a keresztmetszeti jellemzőket kell kiszámítani. 


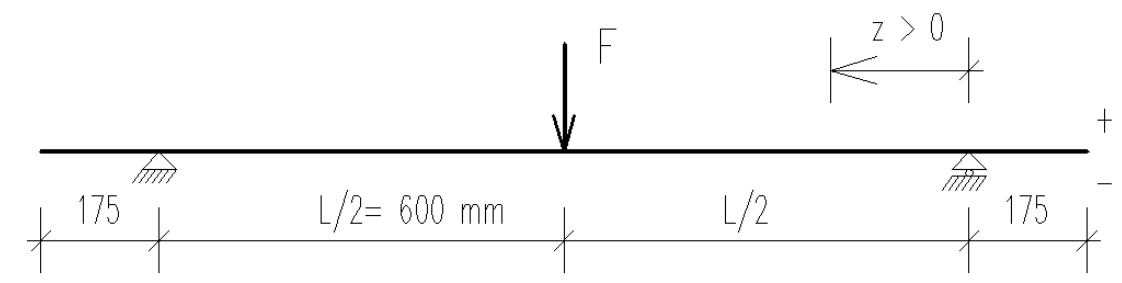

HO homogén keresztmetszet H1 hosszvasalású keresztmetszet
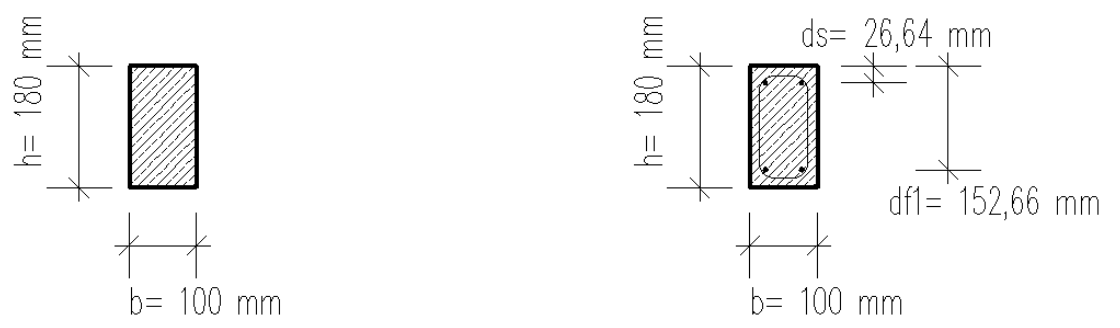

4. ábra: Statikai váz és keresztmetszetek

A H0 repedésmentes homogén keresztmetszet esetében a rugalmas semleges tengely helye a nyomott szélső száltól mérve, valamint a semleges tengelyre vett inercia nyomatéka a 4. ábra jelöléseit használva:

$$
\begin{gathered}
x_{I 0}=\frac{h}{2}=90 \mathrm{~mm}, \\
I_{I 0}=\frac{b \cdot h^{3}}{12}=48600000 \mathrm{~mm}^{4} .
\end{gathered}
$$

Jelölje az FRP és a beton rugalmassági modulusának arányát $\alpha_{f}$, akkor:

$$
\alpha_{f}=\frac{E_{f}}{E_{c m}}=1,83
$$

A H1 erősítésű inhomogén keresztmetszet semleges tengelyének a nyomott szélső száltól vett távolságára, illetve a semleges tengelyre számított inerciájára a következőket kapjuk:

$$
\begin{gathered}
x_{I 1}=\frac{\frac{b \cdot h^{2}}{2}+\left(\alpha_{f}-1\right) \cdot \frac{\phi_{f}^{2} \cdot \pi}{2} \cdot d_{f 1}}{b \cdot h+\left(\alpha_{f}-1\right) \cdot \frac{\phi_{f}^{2} \cdot \pi}{2}}=90,29 \mathrm{~mm}, \\
I_{I 1}=\frac{b \cdot x_{I 1}^{3}}{3}+\frac{b \cdot\left(h-x_{I 1}\right)^{3}}{3}+\left(\alpha_{f}-1\right) \cdot \frac{\phi_{f}^{2} \cdot \pi}{2} \cdot\left(x_{I 1}-d_{f 1}\right)^{2}=48926307,10 \mathrm{~mm}^{4},
\end{gathered}
$$

ahol $\phi_{f}=8 \mathrm{~mm}$ az FRP betétek átmérője és $d_{f 1}=152,66 \mathrm{~mm}$ a betétek súlypontjainak a távolsága a felső szélső száltól (4. ábra). A (4) és (5) egyenletekből látható, hogy az $\alpha_{f}=1$ esetben (azaz, ha keresztmetszet homogén beton) visszakapjuk az (1) és (2) kifejezéseket, illetve a homogén keresztmetszet jellemzőit.

Az állapotjellemzők értékei a jobboldali támasztól mért távolságuk ( $0 \leq z \leq 600 \mathrm{~mm}$, H0 illetve $-175 \mathrm{~mm} \leq z \leq 600 \mathrm{~mm}$ H1 esetében) függvényében vannak megadva a fesztáv felére, a szerkezetre és a terhelésére vonatkozó szimmetria viszonyok miatt. (4. ábra). A vizsgált állapotjellemzők a hosszirányú megerősítéstől függnek, így a fentebb meghatározott keresztmetszeti jellemzőket az alábbi 
függvényekbe behelyettesítve, a homogén és a megerősített keresztmetszetekhez, azaz a G1 és G2 gerendákhoz tartozó állapotjellemzők adódnak az Euler-Bernoulli modell szerint.

\section{A húzott szélső szálban ébredő feszültség}

A beton húzott szélső szálban ébredő feszültséget és annak maximumát az alábbi képletek szerint lehet számítani:

$$
\begin{gathered}
\sigma_{c t I i}(z)=\frac{F \cdot\left(h-x_{I i}\right)}{2 \cdot I_{I i}} \cdot z, \\
\sigma_{\text {ctIimax }}=\sigma_{c t I i}\left(\frac{L}{2}\right)=\frac{F \cdot\left(h-x_{I i}\right)}{4 \cdot I_{I i}} \cdot L,
\end{gathered}
$$

ahol $F=4 k N$ és $L=1200 \mathrm{~mm}$ (4. ábra). Az $i$ alsó index a homogén keresztmetszet esetén $i=0$, míg a H1 vasalású keresztmetszet esetén $i=1$. Ezt a jelölési konvenciót alkalmaztam a többi állapotjellemző esetében is.

A repesztőerő meghatározása

A (7) egyenlet alapján a H0 és H1 keresztmetszetekhez meg tudjuk határozni annak a terhelőerőnek nagyságát, melynek hatására az alsó szélső betonszálban kialakul a beton hajlító-húzó szilárdságának várható értéke $\left(\sigma_{c t I i m a x}=f_{c t m, f l}=3,06 \mathrm{MPa}\right)$. Ez az erő választja el a keresztmetszet repedésmentes és berepedt állapotát, a továbbiakban $F_{c r i}$ szimbólummal jelölöm.

$$
F_{c r i}=\frac{4 \cdot f_{c t m, f l} \cdot I_{I i}}{L \cdot\left(h-x_{I i}\right)}
$$

A keresztmetszeti jellemzők és a repesztőerők értékét az 1. táblázat tartalmazza.

\section{Az FRP betétben ébredő feszültségek tengelyirányú eloszlása (H1 esetén)}

Az alsó sorban elhelyezett FRP betétekre vonatkozó feszültségek tengelyirányú eloszlása, valamint a maximális érték (a középső keresztmetszetben):

$$
\begin{gathered}
\sigma_{f I 1}(z)=\alpha_{f} \cdot \frac{F \cdot\left(d_{f 1}-x_{I 1}\right)}{2 \cdot I_{I 1}} \cdot z, \\
\sigma_{f I 1 \max }=\sigma_{f I 1}\left(\frac{L}{2}\right)=\alpha_{f} \cdot \frac{F \cdot\left(d_{f 1}-x_{I 1}\right)}{4 \cdot I_{I 1}} \cdot L .
\end{gathered}
$$

\section{Az alsó szélső szál lehajlása repedésmentes állapotban}

Általánosan az alsó szál lehajlása és annak (negatív) maximális értéke a támaszközépen a következő kifejezésekkel kaphatók meg:

$$
v_{I i}(z)=\left\{\begin{array}{c}
\frac{F}{4 \cdot E_{c m} \cdot I_{I i}} \cdot\left(\frac{1}{3} \cdot z^{3}-\frac{L^{2}}{4} \cdot z\right), \quad h a 0 \leq z \leq / 2 ; \\
\frac{F \cdot L^{2}}{16 \cdot E_{c m} \cdot I_{I i}} \cdot z, \quad h a-175 \mathrm{~mm} \leq z \leq 0, \text { csak H1 esetében! } \\
v_{\text {Iimax }}=v_{I i}\left(\frac{L}{2}\right)=\frac{-F \cdot L^{3}}{48 \cdot E_{c m} \cdot I_{I i}} .
\end{array}\right.
$$




\begin{tabular}{|c|c|c|c|}
\hline Hosszvasalás & $\begin{array}{c}\text { A semleges } \\
\text { tengely } \\
\text { helye } \\
\boldsymbol{x}_{\boldsymbol{I i}}[\mathbf{m m}]\end{array}$ & $\begin{array}{c}\text { A } \\
\text { repedésmentes } \\
\text { keresztmetszet } \\
\text { inerciája } \\
\boldsymbol{I}_{\boldsymbol{I i}}\left[\mathbf{m m}^{\mathbf{4}}\right]\end{array}$ & $\begin{array}{c}\text { A } \\
\text { repesztőerő } \\
\text { értéke } \\
\boldsymbol{F}_{\text {cri }}[\boldsymbol{k N}]\end{array}$ \\
\hline $\mathrm{H} 0$ & 90,00 & 48600000,00 & 5,5039 \\
\hline $\mathrm{H} 1$ & 90,29 & 48926307,10 & 5,5587 \\
\hline
\end{tabular}

1. táblázat: Keresztmetszeti jellemzők és repesztőerők

\section{A szilárdtest modellek bemutatása}

A szilárdtest modellek az Ansys 2020 R2 program felhasználásával készültek. Hárompontos hajlítónyíró vizsgálat során a gerenda az alsó lapján, két vonal mentén van megtámasztva és a terhelőerő a felső lap keresztirányú szimmetria tengelyén adódik át (1. ábra). Mivel a szerkezet, a terhelés és a keresztmetszet is szimmetrikus, elegendő a gerenda negyedét modellezni. A modellezendő szilárdtest az eredeti gerendából a kereszt- és hosszirányú szimmetria síkokkal van kivágva. Azokon a részeken, ahol a modell elhanyagolt testtel érintkezne, szimmetria peremfeltételek lettek előírva a megfelelő felületi normálisokkal. Ha a negyed modellen az eredeti szerkezet jellemzőit kívánjuk megkapni, a „valóságos” terhelőerő negyedét (azaz $F / 4=1 \mathrm{kNerőt)} \mathrm{kell} \mathrm{terhelésként} \mathrm{megadni.} \mathrm{Elsődleges} \mathrm{cél} \mathrm{az}$ előző fejezetekben említett állapotjellemzők meghatározása (majd összevetése az Euler-Bernoulli modell alapján kapott értékekkel). Repedésmentes állapotban a beton, az acél és az FRP betétek viselkedése is leírható lineárisan rugalmas, izotróp anyagmodellekkel. (A szükséges anyagparamétereket az 1.2 fejezetben adtam meg.) A repedésmentes állapot a terheléstörténet első szakasza, feltételezhető a kis elmozdulások elvének érvényben maradása, így a geometriai linearitás is. A modellekben nincsennek megadva olyan peremfeltételek, melyek esetében nemlinearitással számolni kellene, így elegendő volt a lineáris analíziseket futtatni. A geometriai és a fizikai linearitás miatt érvényes a szuperpozíció elve, mely lehetővé teszi a repesztőerők számítását. A számítások eredményei a következő alpontokban vannak közölve.

\subsection{G1 jelű homogén keresztmetszetű gerenda szilárdtest modelljei}

A G1 gerenda esetében két szilárdtest modell lett felépítve.

\section{Num1G1 modell}

A Num1G1 modell homogén beton keresztmetszettel készült, melynek peremfeltételei a rúdszerkezeti modell szerint lettek felvéve, a terhelést kivéve (5. ábra). A teher a gerenda felső lapjának keresztirányú szimmetria tengelyén lett definiálva (mint a három pontos hajlító-nyíró vizsgálatnál), mivel támaszköz közepén lévő alsó szélső szál távolabb esik a „zavart” résztől, így numerikusan pontosabb eredmény érhető el. (Vizsgálva volt az az eset is, amikor a teher a véglapon oszlott meg, de így az alsó szélső szál tekintetében nem adódott konvergens megoldás.) A szilárdtest méretei: 50×180×600 mm. Az elméleti támaszokon túllógó részek $(2 \times 175$ mm) ebben az esetben nem képezték a vizsgálat tárgyát.

Num2G1 modell 
Ez a Num1G1 modellel megegyező méretekkel és homogén keresztmetszettel, de már a hárompontos hajlító-nyíró vizsgálatnak megfelelő peremfeltételekkel lett felépítve; vonalmenti támaszokkal az alsóés vonalmenti terhelőerővel a felső lapon (6. ábra).

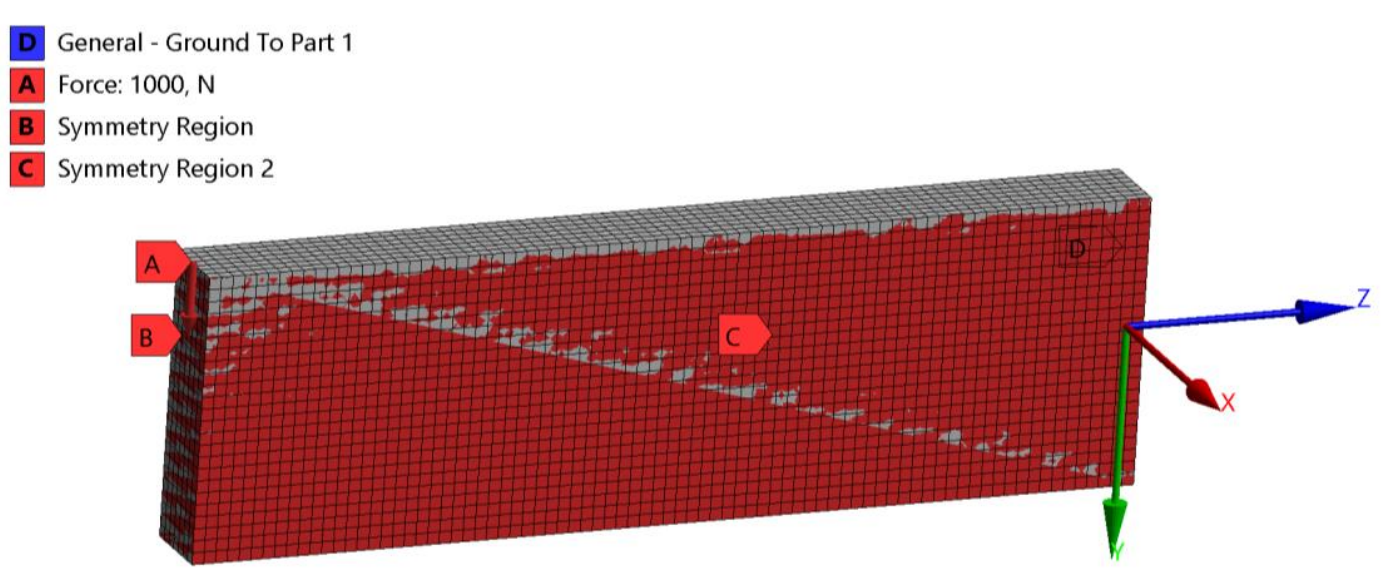

5. ábra: Num1G1 szilárdtest modell peremfeltételei

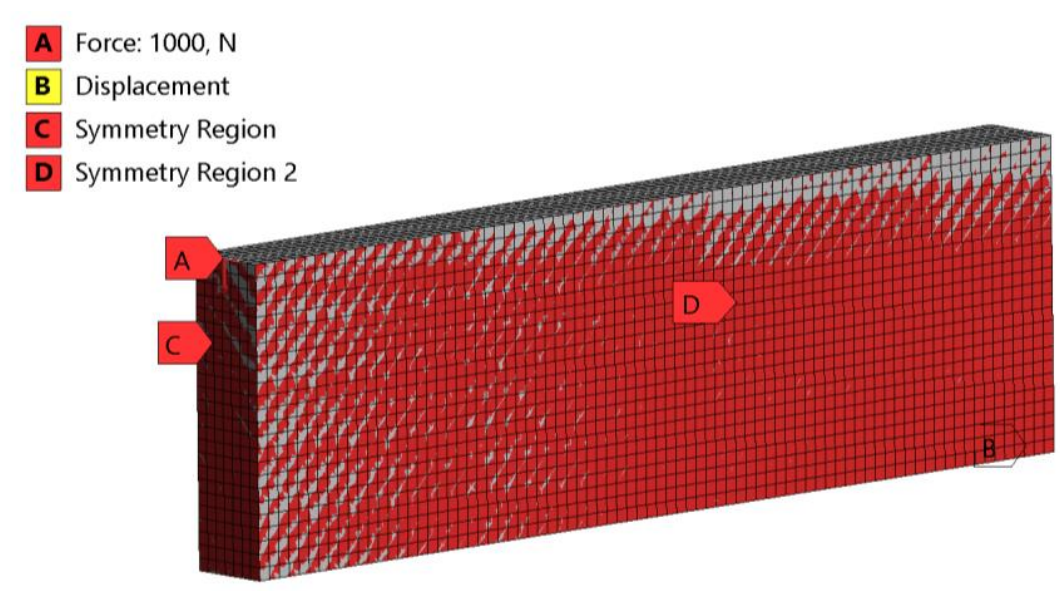

6. ábra: Num2G1 szilárdtest modell peremfeltételei

Eredmények Num1G1 és Num2G1 modellek alapján

\begin{tabular}{|c|c|c|c|}
\hline $\boldsymbol{F}=\mathbf{4} \boldsymbol{k N}$ & $\begin{array}{c}\text { Maximális húzófeszültség } \\
\text { az alsó szélső szálban } \\
\boldsymbol{\sigma}_{\text {ctIimax }}[\boldsymbol{M P a}]\end{array}$ & $\begin{array}{c}\text { Maximális lehajlás } \\
\boldsymbol{v}_{\text {Iimax }}[\mathbf{m m}]\end{array}$ & $\begin{array}{c}\text { A repesztőerő értéke } \\
\boldsymbol{F}_{\boldsymbol{c r i}}[\boldsymbol{k N}]\end{array}$ \\
\hline Num1G1 & 2,1636 & 0,11395 & 5,6512 \\
\hline Num2G1 & 1,335 & 0,0678 & 9,1617 \\
\hline
\end{tabular}

2. táblázat: Állapotjellemző́k a Num1G1 és Num2G1 modelleken

Az alsó szélső szálban keletkező maximális feszültség ismeretében a repesztőerők számíthatók:

$$
F_{c r N u m 1 G 1}=\frac{4 k N \cdot f_{c t m, f l}}{2,1636 \mathrm{MPa}}=5,6512 k N,
$$




$$
F_{c r N u m 2 G 1}=\frac{4 k N \cdot f_{c t m, f l}}{1,335 M P a}=9,1617 k N .
$$

\subsection{G2 jelű gerenda NumG2 szilárdtest modellje}

A G2 modellje $50 \times 180 \times 775 \mathrm{~mm}$ befoglaló méretű téglatestként készült. Hasonlóan a G1 próbatest modelljeihez az inhomogén keresztmetszetű gerendának is a negyede lett megmodellezve. A vonalmenti támasz minden esetben az alsó lapon a $600 \mathrm{~mm}$-re lett elhelyezve a teljes szerkezet keresztirányú szimmetria síkjától. A vonalmenti megoszlóerő a modell felső lapjának szélső keresztirányú élén lett definiálva. A hosszirányú megerősítés és a kengyelek is szilárdtestként lettek beépítve a modellbe.

A homogén keresztmetszetek esetén könnyű volt hexa hálót kialakítani a szabályos geometria miatt. Az inhomogén keresztmetszetnél a kengyelek sarkának lekerekítése, illetve a beton szilárdtest szabálytalansága okán Tet10, Hex30 és Wed15 elemekből épült fel a végeselemháló. A beton elemek mérete 7,5 mm-re, a betét elemek mérete 1,5 mm-re lett beállítva a hálózás során.
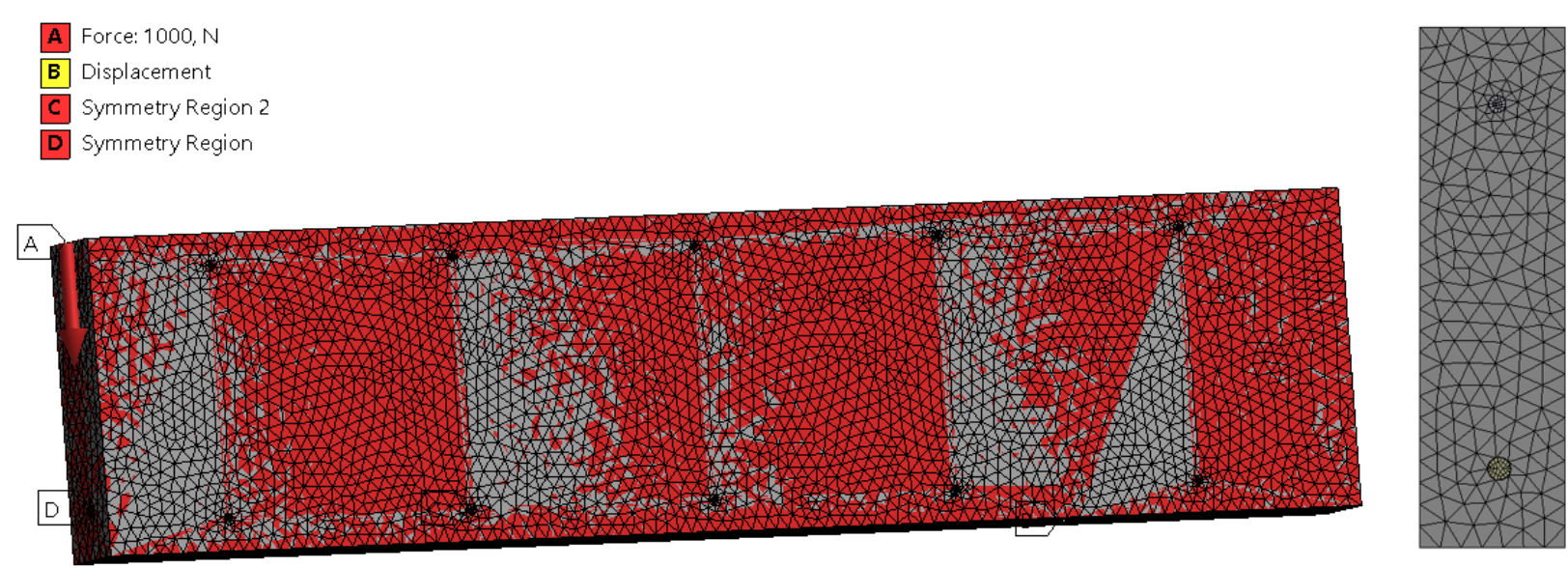

6. ábra: NumG2 szilárdtest modell peremfeltételei és a keresztmetszet

Eredmények a NumG2 modell alapján 
International Journal of Engineering and Management Sciences (IJEMS) Vol. 6. (2021). No. 3

DOI: 10.21791/IJEMS.2021.3.5.
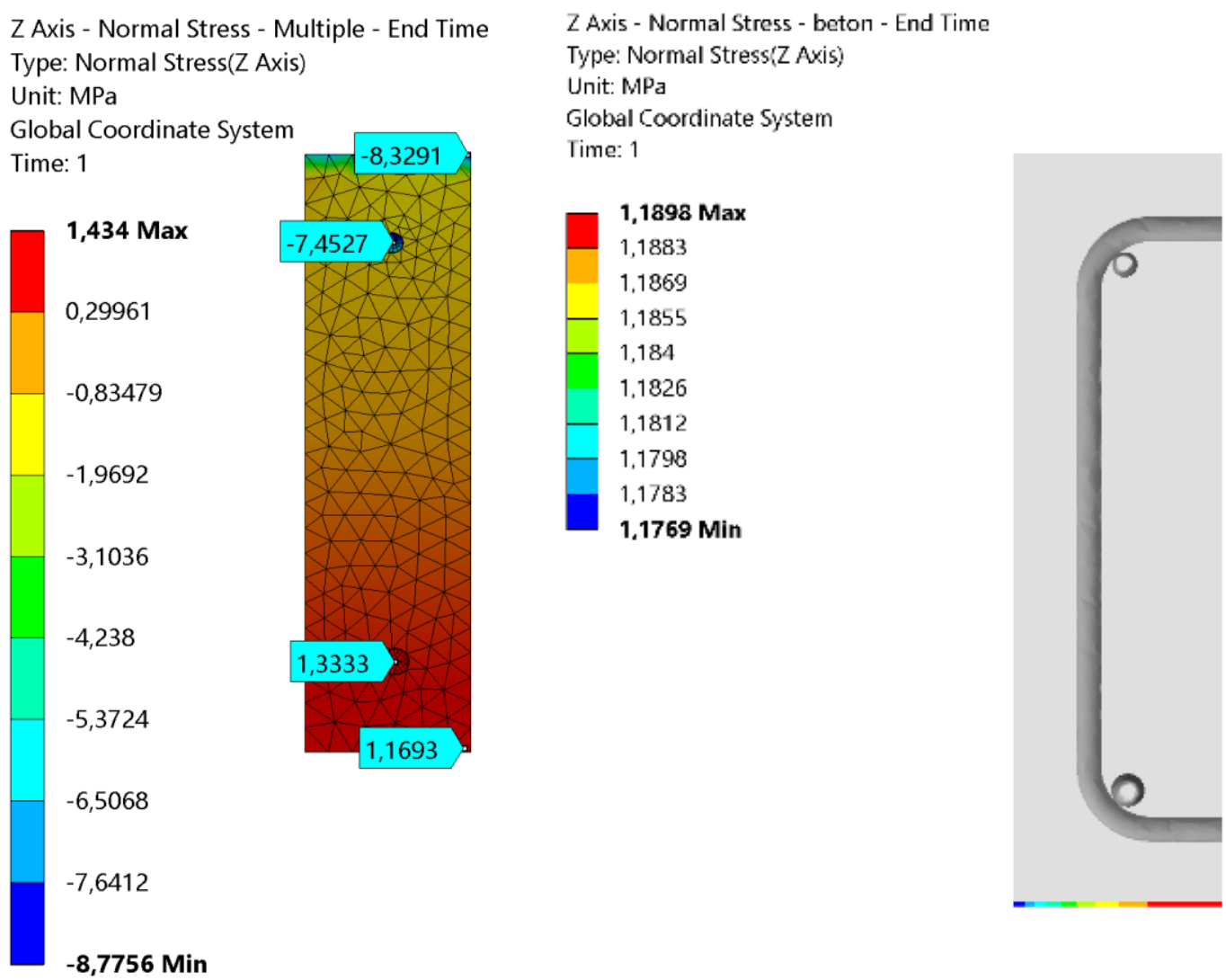

7. ábra: A tengelyirányú normálfeszültség eloszlása a középső keresztmetszetben és a középső keresztmetszet alsó szélső szálán NumG2 szilárdtest modell alapján

A maximális húzófeszültség ismeretében (7. ábra) meghatározható a repesztőerő:

$$
F_{c r N u m 2 G 1}=\frac{4 k N \cdot f_{c t m, f l}}{1,1898 \mathrm{MPa}}=10,2797 \mathrm{kN} .
$$

\section{A modellek összehasonlítása}

Ebben a fejezetben az Euler-Bernoulli modelleken kapott állapotjellemzők összevetését végeztem el a szilárdtest modellek eredményeivel. Az előbbiekre EBG1 és EBG2 jelölés vonatkozik, míg a numerikus modellek esetében a Num1G1, Num2G1 és a NumG2 jelölések lettek alkalmazva.

\subsection{G1 gerenda}




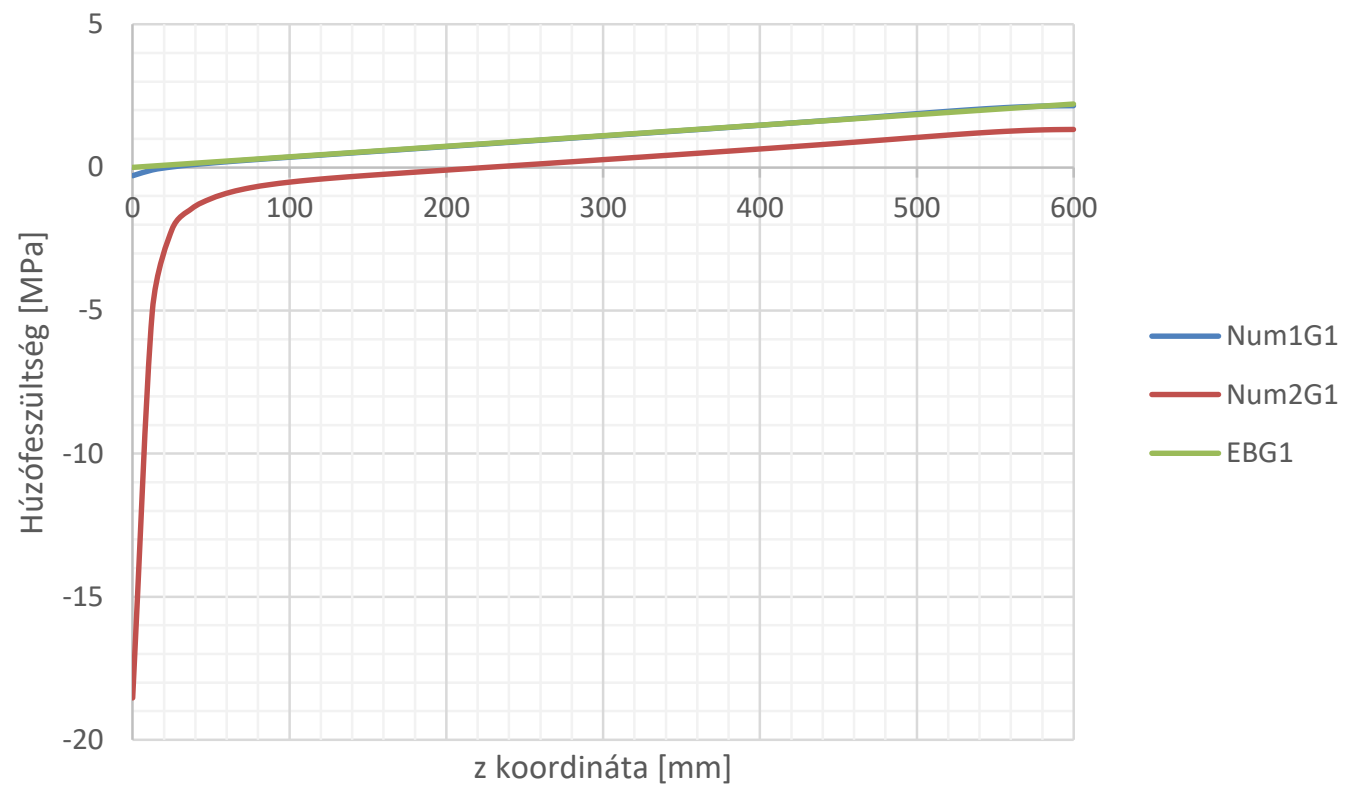

8. ábra: A 4 kN nagyságú terhelésből az alsó szélső szálakban ébredő normálfeszültségek

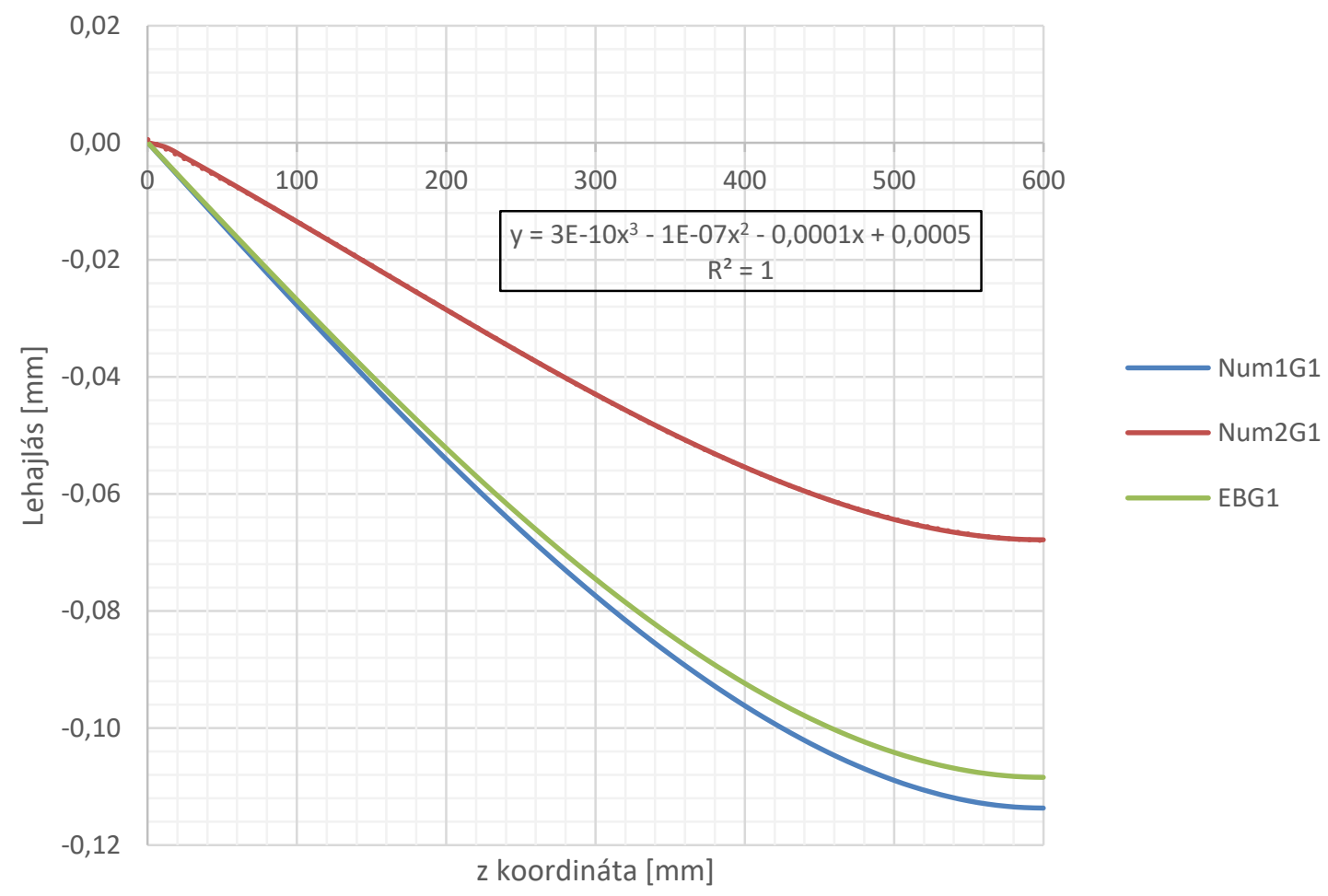

9. ábra: A 4 kN nagyságú terhelésbőll adódó lehajlások

A 8. és 9. ábra alapján elmondható, hogy az Euler-Bernoulli modell szinte teljes egyezést mutat a Num1G1 szilárdtest modellel, ahol a támaszokat a keresztmetszet súlypontjában írtam elő. Viszont a Num2G1 modellnél, ahol a támaszok a hárompontos hajlító-nyíró vizsgálatnak megfelelően lettek modellezve, az tapasztalható, hogy az Euler-Bernoulli modell 38-40\%-kal nagyobb húzófeszültség és lehajlás értéket ad. A nagy eltérések a különböző peremfeltételek alkalmazásából, valamint a 
keresztirányú hatások el nem hanyagolásából erednek (a szilárdtest modelleken). A 8. ábrán látható, hogy a numerikus modell nem ad megbízható eredményt a támaszhoz közel. Ez a várakozásnak megfelel, hiszen a háló sűrítésével a vonalmenti támasznál egyre nagyobb feszültség értékek adódnak, ami nem vezethet konvergens megoldáshoz. A Num2G1 modell szerint, az alsó szélső szálban ébredő feszültség a támasztól $\sim L / 6=200 \mathrm{~mm}$ távolságra vált előjelet. A 9. ábrán látható, hogy a szilárdtest modellen az elemi szilárdságtan eredményeivel egyező módon harmadfokú lehajlásfüggvény adódott.

\subsection{G2 gerenda}

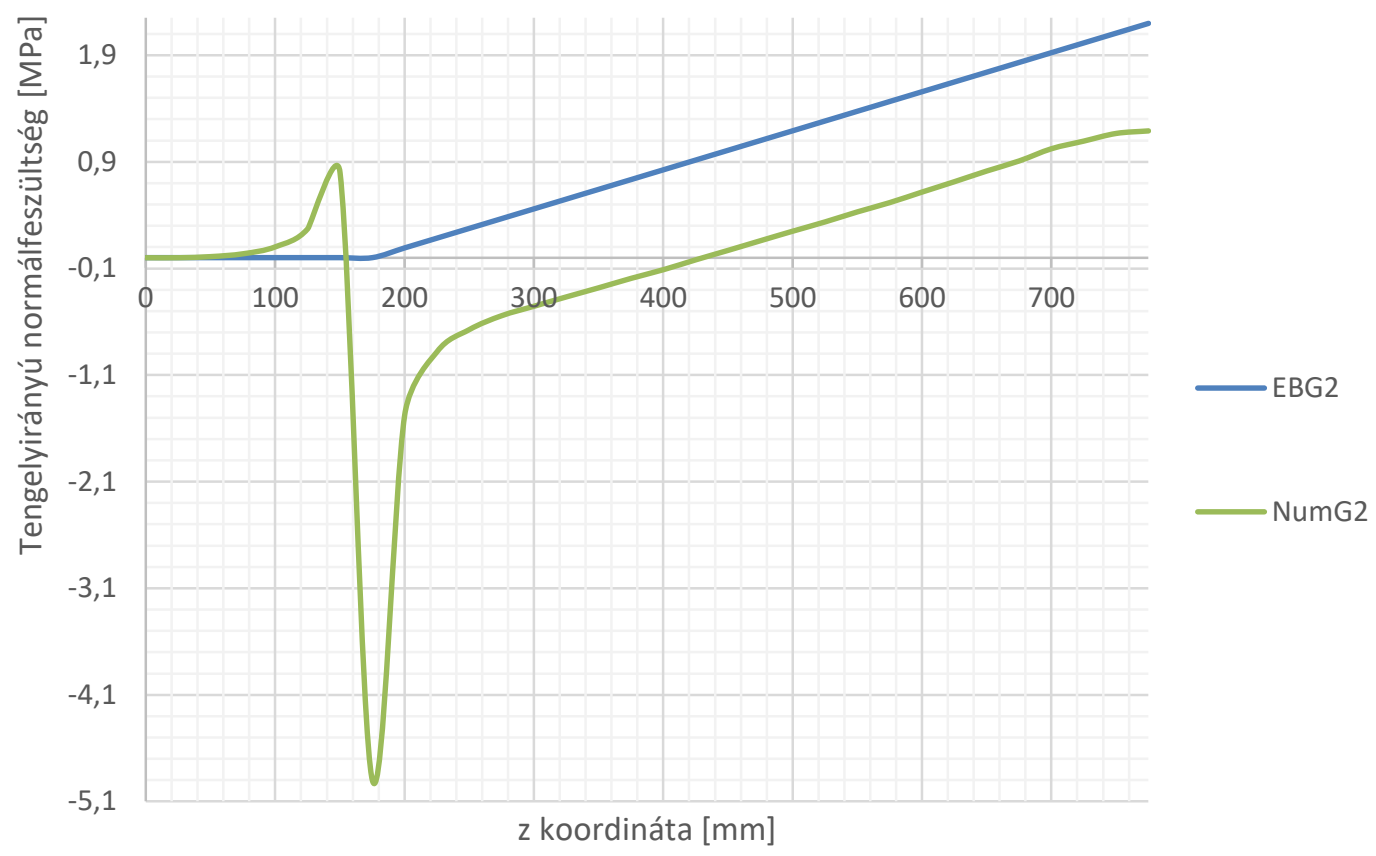

10. ábra: A 4 kN nagyságú terhelésből adódó normálfeszültségek az alsó szélső szálakban 


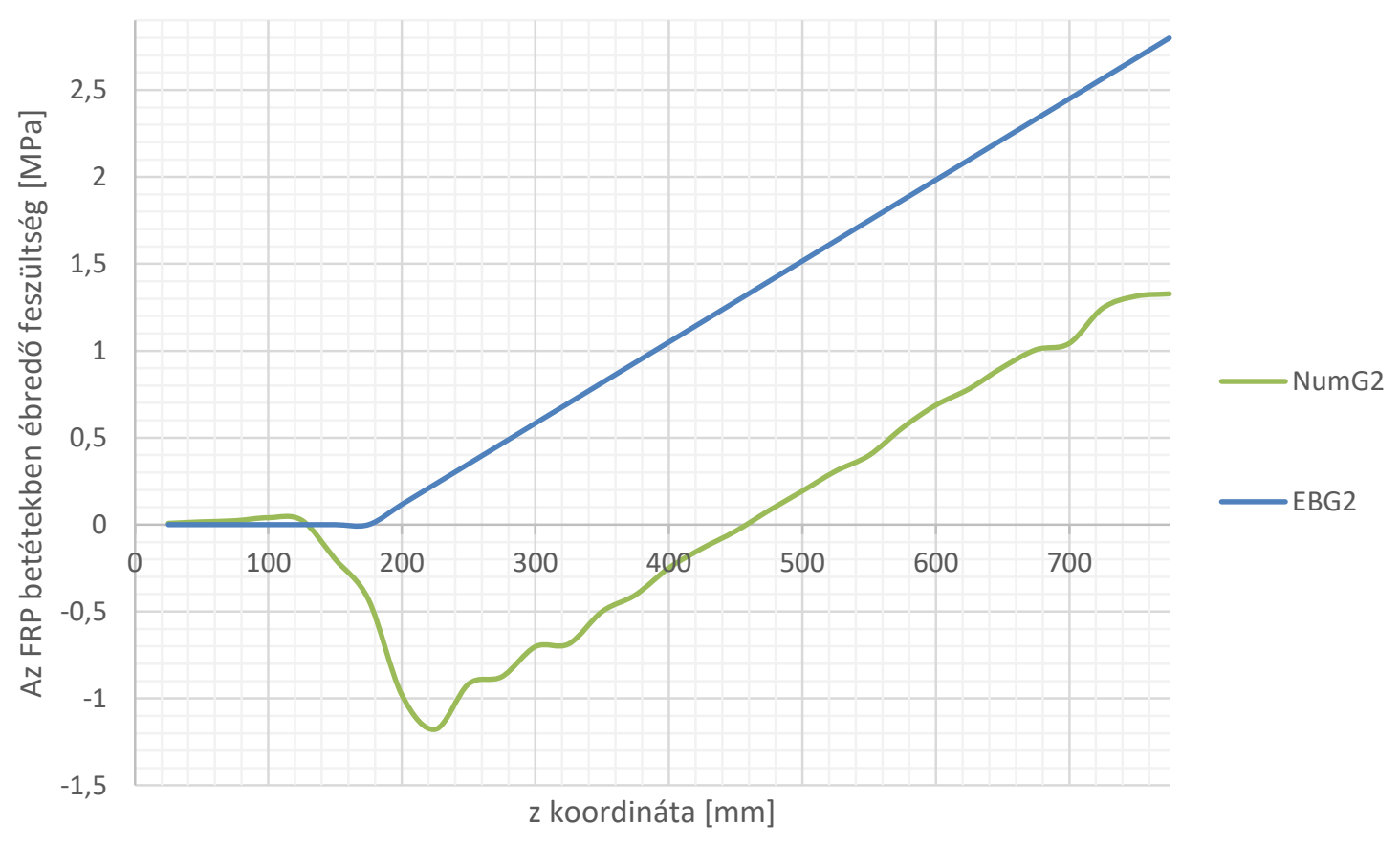

11. ábra: Az FRP betétekben ébredő normálfeszültségek a 4 kN nagyságú terhelés hatására

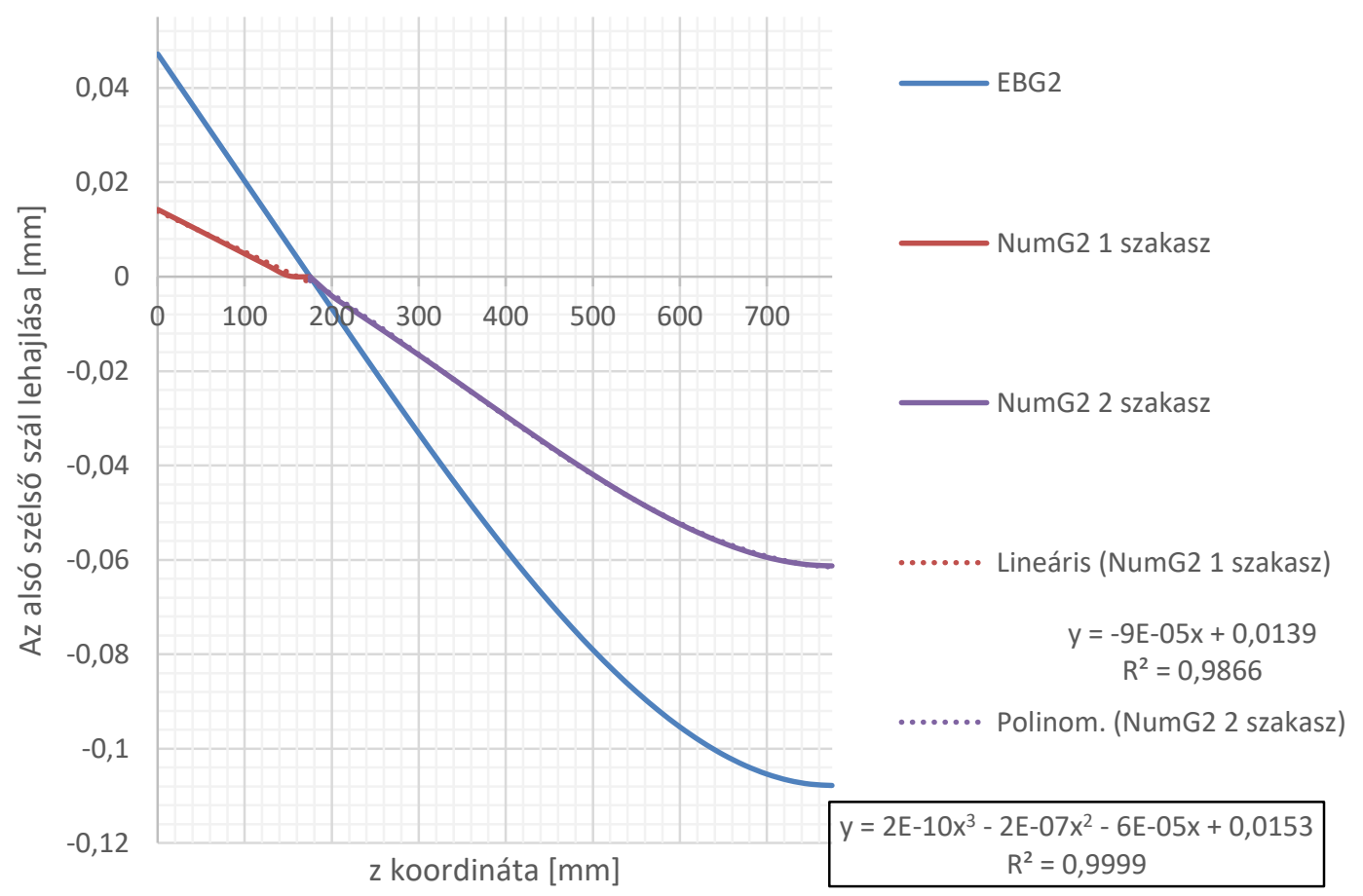

12. ábra: A 4 kN nagyságú terhelés hatására kialakuló lehajlások

A G2 gerenda esetében a támaszon túli szakaszt is tartalmazza a NumG2 modell. A húzófeszültségek és a lehajlások tekintetében hasonlóak az eredmények, mint a G1 gerendánál. Itt is megfigyelhető a támasznál kialakuló szinguláris jelenség és az alsó szélső szál feszültségének előjel váltása a támasztól körülbelül 200 mm-re $(\sim L / 6)$. 
Az FRP betétekben kialakuló feszültség eloszlásában is nagy különbség tapasztalható a kétféle modell között (11. ábra). A numerikus modell esetében a feszültség függvény kétszer is előjelet vált és a kengyelek környezetében „hullámzást” mutat. Az utóbbi jelenség a kengyelszárak görbületénél átadódó keresztirányú feszültségek miatti többlet normálfeszültségekből adódik. A klasszikus modellhez hasonlóan a NumG2 alapján számított lehajlás függvény támaszon túli szakasza lineáris, míg a támaszokon belül jó közelítéssel harmadfokú.

\section{5. Összefoglalás}

A 3. táblázatban vannak összefoglalva az állapotjellemzők értékei az Euler-Bernoulli, valamint a numerikus modellek alapján, a G1 és G2 gerendák esetében. A 3. táblázat 4. és 7. sora a numerikus modellek eredményeinek relatív eltéréseit tartalmazza az Euler-Bernoulli modelleken meghatározott jellemzőkhöz képest. Az előző pontok eredményei alapján elmondható, hogy a kézi számításokban elterjedt Euler-Bernoulli modell és a térbeli szilárdtest modellek (melyekben vonalmenti megtámasztás volt definiálva az alsó lapokon) alapján meghatározott állapotjellemzőkben jelentős eltérések tapasztalhatók. Az EBG1 és Num1G1 modellek eredményeinek összehasonlításából (8. és 9. ábrák) látszik, hogy eltérések főként a különböző támaszmodellek alkalmazásából adódnak, valamint kis mértékben szerepet kapnak a keresztirányú hatások és a tényleges térbeli feszültségállapot kialakulása is.

\begin{tabular}{|c|c|c|c|c|c|}
\hline & $\begin{array}{c}\boldsymbol{F}= \\
4 k N\end{array}$ & $\begin{array}{c}\sigma_{c t I i m a x} \\
{[M P a]}\end{array}$ & $\begin{array}{c}\sigma_{f 1 \text { IImax }} \\
{[M P a]}\end{array}$ & $\begin{array}{l}\boldsymbol{v}_{\text {Iimax }} \\
{[\mathrm{mm}]}\end{array}$ & $\begin{array}{l}\boldsymbol{F}_{\boldsymbol{c r i}} \\
{[k N]}\end{array}$ \\
\hline \multirow{3}{*}{$\underline{\text { G1 }}$} & EBG1 & 2,222 & - & $-0,1085$ & 5,5039 \\
\hline & Num2G1 & 1,335 & - & $-0,0678$ & 9,1617 \\
\hline & Eltérés [\%] & -40 & - & -38 & 66 \\
\hline \multirow{3}{*}{ G2 } & EBG2 & 2,2003 & 2,8002 & $-0,1078$ & 5,5587 \\
\hline & NumG2 & 1,1898 & 1,3271 & $-0,0612$ & 10,2797 \\
\hline & Eltérés [\%] & -46 & -53 & -43 & 85 \\
\hline
\end{tabular}

3. táblázat: Állapotjellemzők összevetése az Euler-Bernoulli- és a szilárdtest modellek alapján

Az 1. ábrán megjelenő hárompontos hajlító-nyíró vizsgálat esetében, az Euler-Bernoulli modellnek megfelelő, 4. ábra szerinti statikai váznak az alkalmazása a térbeli szilárdtest modellekhez képest jelentősen a biztonság javára közelíti a valóságot az alkalmazott keresztmetszetek és anyagjellemzők esetében. 
International Journal of Engineering and Management Sciences (IJEMS) Vol. 6. (2021). No. 3

DOI: 10.21791/IJEMS.2021.3.5.

\section{Hivatkozások}

[1] Balázs, G. and L. Balázs, G. (2013) Különleges betonok és betontechnológiák V. Budapest: Akadémiai Kiadó

[2] fib (2007) FRP reinforcement in RC structures.

[3] Nanni, A., De Luca, A. and Zadeh, H. J. (2014) Concrete with FRP Bars Mechanics and Design. Boca Raton: Taylor \& Francis Group.

[4] MSZ EN 1992-1-1:2010 Eurocode 2: Betonszerkezetek tervezése (2010)

[5] Więch, P. and Głodkiewicz, J. (2015) TEST REPORT No. LK00-01111/14/Z00NK. Warsaw

[6] Sólyom, S. and L. Balázs, G. (2015) 'Szálerősítésű polimer (FRP) betétek-1. Anyagjellemzők', Vasbetonépítés, XVII(1), pp. 13-16.

[7] Kaliszky, S. Kurutzné Kovács, M. és Szilágyi, G. (2000) Szilárdságtan. Budapest: Nemzeti Tankönyvkiadó. 